[Article]

www.whxb.pku.edu.cn

\title{
三聚氰胺的生成焓、热容和熵
}

\author{
刘 鹏 ${ }^{1, *}$ 熊 伟 ${ }^{1}$ 胡善洲 ${ }^{1}$ 李 曦 ${ }^{1}$ 谭志诚 ${ }^{2}$ \\ ('武汉理工大学理学院化学系, 武汉 $430070 ;{ }^{2}$ 中国科学院大连化学物理研究所热化学实验室和 \\ 中国离子液体实验室, 辽宁大连 116023)
}

\begin{abstract}
摘要: 通过多种热化学方法研究了三聚诵胺的热力学性质. 首先用氧弹式燃烧热量计测定了三聚氨胺在 298.15 $\mathrm{K}$ 时的燃烧热, 根据燃烧热结果, 计算出三聚氨胺的标准摩尔燃烧焓和标准摩尔生成焓, 分别为: $\Delta_{\mathrm{c}} H_{\mathrm{m}}^{\ominus}=$ $(-2455.17 \pm 4.65) \mathrm{kJ} \cdot \mathrm{mol}^{-1} ; \Delta_{\mathrm{i}} H_{\mathrm{m}}^{\ominus}=(-763.38 \pm 5.16) \mathrm{kJ} \cdot \mathrm{mol}^{-1}$. 然后根据键焓与燃烧焓之间的关系, 估算出三聚氧胺中 的 $\mathrm{C} \approx \mathrm{N}$ (此键介于单键与双键之间) 键能为 $458.30 \mathrm{~kJ} \cdot \mathrm{mol}^{-1}$, 此值介于碳氮单键键能和双键键能之间. 通过绝热 热量计测定了三聚氨胺从 80 到 $385 \mathrm{~K}$ 的低温热容. 根据热容值, 计算了此温度区间的标准摩尔生成焓, 其与温 度呈线性关系. 另外, 三聚氨胺的热稳定性也用热重-差示扫描量热(TG-DSC)法进行了分析, 确定其分解的 DSC 曲线的峰顶温度为 $603.37 \mathrm{~K}$.
\end{abstract}

关键词：热容; 三聚㲵胺; 燃烧热; 绝热热量计 中图分类号: $\mathrm{O} 642$

\section{Enthalpy of Formation, Heat Capacity and Entropy of Melamine}

\author{
LIU Peng ${ }^{1, *} \quad$ XIONG Wei ${ }^{1} \quad$ HU Shan-Zhou ${ }^{1} \quad$ LI Xi $^{1} \quad$ TAN Zhi-Cheng ${ }^{2}$ \\ ('Deparment of Chemistry, School of Sciences, Wuhan University of Technology, Wuhan 430070, P. R. China; \\ ${ }^{2}$ Thermochemisty Laboratory and China Ionic Liquid Laoratory, Dalian Institute of Chemical Physics, \\ Chinese Academy of Sciences, Dalian１16023, Liaoning Province, P. R. China)
}

\begin{abstract}
The thermodynamic properties of melamine were studied by multiple thermochemical methods. A bomb combustion calorimeter was used to determine the combustion heat of melamine at $298.15 \mathrm{~K}$. According to the results, we calculated the standard molar enthalpy of combustion and standard molar enthalpy of formation of melamine: $\Delta_{\mathrm{c}} H_{\mathrm{m}}^{\ominus}=$ $(-2455.17 \pm 4.65) \mathrm{kJ} \cdot \mathrm{mol}^{-1} ; \Delta_{\mathrm{f}} H_{\mathrm{m}}^{\ominus}=(-763.38 \pm 5.16) \mathrm{kJ} \cdot \mathrm{mol}^{-1}$. The bond enthalpy of $\mathrm{C} \approx \mathrm{N}$ (between single bond and double bond) in melamine was then estimated to be $458.30 \mathrm{~kJ} \cdot \mathrm{mol}^{-1}$ according to the ralationship between bond enthalpy and combustion enthalpy. This value is larger than that of $\mathrm{C}-\mathrm{N}$ but smaller than that of $\mathrm{C}=\mathrm{N}$. Heat capacity measurements were carried out in a small sample adiabatic calorimeter from 80 to $385 \mathrm{~K}$. We obtained $\Delta_{\mathrm{f}} H_{\mathrm{m}}^{\ominus}$ at different temperatures between 80 and $385 \mathrm{~K}$ using the heat capacity data. Through calculation with the values of heat capacity, the relationship between the standard molar enthalpy of formation and temperature is also presented as a functional equation. We also measured the thermol stability of melamine by the thermogravimetry-differential scanning calorimetry (TG-DSC) technique, which showed a thermal decomposition peak at $603.37 \mathrm{~K}$ for the DSC curve.
\end{abstract}

Key Words: Heat capacity; Melamine; Combustion heat; Adiabatic calorimeter

Melamine (molecular structure: Fig.1; formula: $\mathrm{C}_{3} \mathrm{H}_{6} \mathrm{~N}_{6}$; molecular mass: $\left.126.12 \mathrm{~g} \cdot \mathrm{mol}^{-1}\right)$ is an organic base and a trimer of cyanamide, with a 1,3,5-triazine skeleton. Like cyanamide, it contains $66 \%$ (mass fraction) nitrogen and, if mixed with resins, has fire retardant properties due to its release of nitrogen gas when burned or charred, and has several other industrial uses ${ }^{[1-5]}$.

Received: July 10, 2009; Revised: August 9, 2009; Published on Web: September 28, 2009.

"Corresponding author. Email: chemliup@ whut.edu.cn; Tel: +86-27-63410197; Fax: +86-27-87863157.

The projet was supported by the National Natural Science Foundation of China (50702040).

国家自然科学基金(50702040)资助项目

(C) Editorial office of Acta Physico-Chimica Sinica 
<smiles>Nc1nc(N)nc(N)n1</smiles>

Fig.1 Structure diagram of melamine

Melamine is also a metabolite of cyromazine, a pesticide ${ }^{[6]}$. Melamine is combined with formaldehyde to produce melamine resin, a very durable thermosetting plastic used in Formica, and melamine foam, a polymeric cleaning product ${ }^{[7]}$. Melamine also enters the fabrication of melamine poly-sulfonate used as super plasticizer for making high-resistance concrete ${ }^{[8]}$. The use of melamine as fertilizer for crops had been envisaged during the 1950s and 1960s because of its high nitrogen content.

Melamine is sometimes illegally added to food products in order to increase the apparent protein content. Standard test, such as the Kjeldahl and Dumas tests, estimate protein levels by measuring the nitrogen content ${ }^{[9-11]}$, so they can be misled by adding nitrogen-rich compounds such as melamine. In September 2008, several companies were implicated in a scandal involving milk infant formula which had been adulterated with melamine, leading to kidney stones and other renal failure, especially among young children.

Because the thermodynamics of a compound is involved in the quantitative studies on the energetic, these parameters are very important for the quantum chemistry, computer-aided molecular designs of drugs and new materials, and biochemical reactions. As a common compound, melamine has caused the shock in the field of food safety. However, the mechanism how melamine becomes kidney stones in body is not very clear. One possible reason is that melamine combines with cyanuric acid to form melamine cyanurate, then settled in renal ${ }^{[12-15]}$. So there is a need for studying the thermodynamic parameters of melamine to calculate the thermodynamic properties of the reaction involved with melamine in body. In the present study, an adiabatic calorimeter was used to determine the heat capacity of melamine in the temperature range from 80 to $385 \mathrm{~K}$. Besides, we tried to measure the standard molar enthalpy of formation of melamine by combustion heat at $298.15 \mathrm{~K}$. Thermal analysis technique was used to evaluate the heat stability of melamine.

\section{Experimental}

\subsection{Materials}

Anhydrous melamine (solid) was bought from Bodi Chemical Corporation of Tianjin and its purity was above $99.5 \%$. Its molecular structure is shown in Fig.1.

\subsection{Methods}

\subsubsection{Measurement of enthalpy of combustion}

The combustion heat of melamine was measured by Bomb Combustion Calorimeter (Changsha Instrumental, SF-GR3500, China). The temperature of the water thermostat was maintained at $T=298.15 \mathrm{~K}$. The water temperature in the caloritube was subsequently adjusted to be lower than that of the water thermostat. A known amount of twice distilled water was added into the calorimeter. When the sample was placed in the crucible fixed on the support in the bomb, the Ni wire was fixed in the bomb. After the bomb was filled with $2.4 \mathrm{MPa}$ oxygen gas, it was sealed. Before the calorimetric test, the calorimeter was set up well. It was important to keep up a constant temperature change rate in the calorimeter at the beginning of the experiment. In the early period of the experiment, the magnitudes of the temperature were recorded $v s$ time typically with one entry every $5 \mathrm{~s}$. Then the sample was ignited until the main period of the combustion reaction was finished. In the later period of the experiment, the magnitudes of the temperature were recorded in the early period of the experiment. After the experiment was accomplished, the final products of the combustion reaction were analyzed. The change of temperature was recoded. The analysis methods have been discussed in the literature ${ }^{[16]}$. The analytical results of the final solution showed that the combustion reactions were complete. Neither carbon deposits nor carbon monoxide was formed during the combustion reactions. The amount of $\mathrm{NO}_{x}$ in the final gas was insignificant. The NIST standard reference material, benzoic acid, was used to calibrate the combustion calorimeter ${ }^{[17]}$.

\subsubsection{Measurement of molar heat capacity of melamine}

The heat capacity measurement was carried out in a small sample adiabatic calorimeter over the temperature range from 80 to $385 \mathrm{~K}$. The adiabatic calorimeter was constructed in the Dalian Institute of Chemical Physics, Chinese Academy of Sciences, the detailed description of which has been described in the literature ${ }^{[18-21]}$. Before the experiment, the molar heat capacities of synthetic sapphire $\left(\mathrm{Al}_{2} \mathrm{O}_{3}\right.$, standard reference material 720 , National Institute of Standards and Technology) were measured in the same temperature range to verify the reliability of the adiabatic calorimeter. The deviations of the experimental results from the recommended values of NIST were within $\pm 0.5 \%$ from 80 to $385 \mathrm{~K}$.

1.2.3 Thermol stability of melamine determined by TG-DSC

The TG-DSC instrument (NETZSCH STA 449 C) was run under sub-ambient temperature conditions. The sample chamber was purged with dry nitrogen at $10 \mathrm{~mL} \cdot \mathrm{min}^{-1}$. The heating rate was $10 \mathrm{~K} \cdot \mathrm{min}^{-1}$, and the temperature range was from room temperature to $773 \mathrm{~K}$.

\section{Results and discussion}

The constant-volume energy of combustion of melamine, $\Delta_{\mathrm{c}} U_{\mathrm{m}}^{\ominus}$, was $-(2451.45 \pm 4.65) \mathrm{kJ} \cdot \mathrm{mol}^{-1}$, which was determined by a combustion calorimeter for five times. The standard molar enthalpy of combustion of melamine, $\Delta_{\mathrm{c}} H_{\mathrm{m}}^{\ominus}$, refers to the combustion enthalpy change of the following ideal combustion reaction at $T=298.15 \mathrm{~K}$ and $p=101.325 \mathrm{kPa}$.

$$
\mathrm{C}_{3} \mathrm{H}_{6} \mathrm{~N}_{6}(\mathrm{~s})+\frac{9}{2} \mathrm{O}_{2}(\mathrm{~g}) \Rightarrow 3 \mathrm{CO}_{2}(\mathrm{~g})+3 \mathrm{~N}_{2}(\mathrm{~g})+3 \mathrm{H}_{2} \mathrm{O}(\mathrm{l})
$$

The standard molar enthalpy of combustion of melamine was 
Table 1 The estimation of molar enthalpy of combustion of melamine by bond enthalpies

\begin{tabular}{|c|c|c|c|c|c|}
\hline Bond of reactant & Number & Average bond enthalpy $\left(\mathrm{kJ} \cdot \mathrm{mol}^{-1}\right)$ & Bond of product & Number & Average bond enthalpy $\left(\mathrm{kJ} \cdot \mathrm{mol}^{-1}\right)$ \\
\hline $\mathrm{C} \approx \mathrm{N}$ & 6 & $\Delta_{\mathrm{b}} H_{\mathrm{C}=\mathrm{N}}^{\ominus}$ & $\mathrm{C}=\mathrm{O}\left(\mathrm{CO}_{2}\right)$ & $3 \times 2=6$ & 799 \\
\hline $\mathrm{C}-\mathrm{N}$ & 3 & 293 & $\mathrm{O}-\mathrm{H}\left(\mathrm{H}_{2} \mathrm{O}\right)$ & $3 \times 2=6$ & 463 \\
\hline $\mathrm{O}=\mathrm{O}\left(\mathrm{O}_{2}\right)$ & 4.5 & 495 & $\mathrm{~N} \equiv \mathrm{N}\left(\mathrm{N}_{2}\right)$ & 3 & 954.4 \\
\hline $\mathrm{N}-\mathrm{H}$ & 6 & 354 & & & \\
\hline
\end{tabular}

calculated from the constant-volume energy of combustion at $T=298.15 \mathrm{~K}$ by the following equation:

\section{$\Delta_{\mathrm{c}} H_{\mathrm{m}}^{\ominus}=\Delta_{\mathrm{c}} U_{\mathrm{m}}^{\ominus}+\Delta(p V)=\Delta_{\mathrm{c}} U_{\mathrm{m}}^{\ominus}+\Delta n \cdot R T$}

$\Delta n=\Sigma n$ (products, $\mathrm{g})-\sum n($ reactants, $\mathrm{g})$ where $n$ is the total amount (in mol) of gas present as products or reactants, $\Delta n=-1.5 \mathrm{~mol}, R=8.314 \mathrm{~J} \cdot \mathrm{mol}^{-1} \cdot \mathrm{K}^{-1}, T=298.15 \mathrm{~K}$. We could obtain the standard molar enthalpy of reaction, $\Delta_{\mathrm{c}} H_{\mathrm{m}}^{\ominus}=$ $(-2455.17 \pm 4.65) \mathrm{kJ} \cdot \mathrm{mol}^{-1}$. With the standard enthalpy of formation of $\mathrm{CO}_{2}(\mathrm{~g})$ and $\mathrm{H}_{2} \mathrm{O}(\mathrm{l})$ at $298.15 \mathrm{~K}$, the standard molar enthalpy of formation of melamine could be obtained, $\Delta_{\mathrm{f}} H_{\mathrm{m}}^{\ominus}=(-763.38 \pm$
$5.16) \mathrm{kJ} \cdot \mathrm{mol}^{-1}$.

The enthalpy of combustion reaction of melamine could also be estimated by the average bond enthalpies without considering the intermolecular forces ${ }^{[22-24]} . \Delta_{\mathrm{c}} H_{\mathrm{m}}^{\ominus}=\sum$ (bond enthalpies of bonds broken) $-\sum$ (bond enthalpies of bonds formed). Because the melamine is of aromaticity, the bond of $\mathrm{C} \approx \mathrm{N}$ on the ring is equivalent. The bond enthalpy of $\mathrm{C} \approx \mathrm{N}$ could be calculated from the molar enthalpy of combustion of melamine. The process of calculation was shown in Table 1 . The bond enthalpy of $\mathrm{C} \approx \mathrm{N}$ is $458.30 \mathrm{~kJ} \cdot \mathrm{mol}^{-1}$. The reported bond enthalpies for $\mathrm{C}-\mathrm{N}$ and

Table 2 Calculated thermodynamic data of melamine

\begin{tabular}{|c|c|c|c|c|c|c|c|c|c|}
\hline$T / \mathrm{K}$ & $\frac{C_{p, \mathrm{~m}}}{\left(\mathrm{~J} \cdot \mathrm{K}^{-1} \cdot \mathrm{mol}^{-1}\right)}$ & $\frac{\left(\Delta_{\mathrm{r}} H_{\mathrm{m}, 298.15 \mathrm{~K}}^{\ominus}-\Delta_{\mathrm{f}} H_{\mathrm{m}, T}^{\ominus}\right)}{\left(\mathrm{kJ} \cdot \mathrm{mol}^{-1}\right)}$ & $\frac{\left(S_{\mathrm{m}, 298.15 \mathrm{~K}}^{\ominus}-S_{\mathrm{m}, T}^{\ominus}\right)}{\left(\mathrm{J} \cdot \mathrm{K}^{-1} \cdot \mathrm{mol}^{-1}\right)}$ & $\frac{\Delta_{\mathrm{f}} H_{\mathrm{m}, T}^{\ominus}}{\left(\mathrm{kJ} \cdot \mathrm{mol}^{-1}\right)}$ & $T / \mathrm{K}$ & $\frac{C_{p, \mathrm{~m}}}{\left(\mathrm{~J} \cdot \mathrm{K}^{-1} \cdot \mathrm{mol}^{-1}\right)}$ & $\frac{\left(\Delta_{\mathrm{f}} H_{\mathrm{m} 2298.15 \mathrm{~K}}^{\ominus}-\Delta_{\mathrm{f}} H_{\mathrm{m}, T}^{\ominus}\right.}{\left(\mathrm{kJ} \cdot \mathrm{mol}^{-1}\right)}$ & $\frac{\left(S_{\mathrm{m}, 298.15 \mathrm{~K}}^{\ominus}-S_{\mathrm{m}, T}^{\ominus}\right)}{\left(\mathrm{J} \cdot \mathrm{K}^{-1} \cdot \mathrm{mol}^{-1}\right)}$ & $\frac{\Delta_{\mathrm{f}} H_{\mathrm{m}, T}^{\ominus}}{\left(\mathrm{kJ} \cdot \mathrm{mol}^{-1}\right)}$ \\
\hline 80 & 41.462 & -20.781 & -110.067 & -784.161 & 240 & 121.531 & -7.880 & -29.296 & -771.260 \\
\hline 85 & 43.851 & -20.568 & -107.482 & -783.948 & 245 & 124.041 & -7.266 & -26.762 & -770.646 \\
\hline 90 & 46.316 & -20.342 & -104.903 & -783.722 & 250 & 126.514 & -6.639 & -24.231 & -770.019 \\
\hline 95 & 48.808 & -20.105 & -102.330 & -783.485 & 255 & 128.952 & -6.000 & -21.699 & -769.380 \\
\hline 100 & 51.294 & -19.854 & -99.762 & -783.234 & 260 & 131.356 & -5.350 & -19.172 & -768.730 \\
\hline 105 & 53.755 & -19.592 & -97.199 & -782.972 & 265 & 133.728 & -4.687 & -16.646 & -768.067 \\
\hline 110 & 56.182 & -19.317 & -94.644 & -782.697 & 270 & 136.072 & -4.012 & -14.124 & -767.392 \\
\hline 115 & 58.573 & -19.030 & -92.096 & -782.410 & 275 & 138.392 & -3.326 & -11.605 & -766.706 \\
\hline 120 & 60.931 & -18.731 & -89.555 & -782.111 & 280 & 140.691 & -2.629 & -9.091 & -766.009 \\
\hline 125 & 63.265 & -18.421 & -87.022 & -781.801 & 285 & 142.975 & -1.919 & -6.581 & -765.299 \\
\hline 130 & 65.583 & -18.098 & -84.497 & -781.478 & 290 & 145.247 & -1.199 & -4.075 & -764.579 \\
\hline 135 & 67.897 & -17.765 & -81.978 & -781.145 & 295 & 147.511 & -0.467 & -1.574 & -763.847 \\
\hline 140 & 70.217 & -17.419 & -79.466 & -780.799 & 298.15 & 148.935 & 0.000 & 0.000 & -763.380 \\
\hline 145 & 72.553 & -17.063 & -76.961 & -780.443 & 300 & 149.770 & 0.276 & 0.924 & -763.104 \\
\hline 150 & 74.914 & -16.694 & -74.460 & -780.074 & 305 & 152.024 & 1.030 & 3.417 & -762.349 \\
\hline 155 & 77.306 & -16.313 & -71.963 & -779.693 & 310 & 154.275 & 1.797 & 5.906 & -761.584 \\
\hline 160 & 79.735 & -15.921 & -69.469 & -779.301 & 315 & 156.522 & 2.574 & 8.392 & -760.807 \\
\hline 165 & 82.203 & -15.516 & -66.977 & -778.896 & 320 & 158.762 & 3.362 & 10.874 & -760.018 \\
\hline 170 & 84.712 & -15.099 & -64.485 & -778.479 & 325 & 160.992 & 4.161 & 13.353 & -759.219 \\
\hline 175 & 87.261 & -14.669 & -61.993 & -778.049 & 330 & 163.205 & 4.972 & 15.828 & -758.408 \\
\hline 180 & 89.846 & -14.226 & -59.498 & -777.606 & 335 & 165.396 & 5.793 & 18.299 & -757.587 \\
\hline 185 & 92.464 & -13.770 & -57.001 & -777.15 & 340 & 167.557 & 6.626 & 20.766 & -756.755 \\
\hline 190 & 95.109 & -13.301 & -54.501 & -776.681 & 345 & 169.680 & 7.469 & 23.229 & -755.911 \\
\hline 195 & 97.775 & -12.819 & -51.997 & -776.199 & 350 & 171.758 & 8.322 & 25.686 & -755.058 \\
\hline 200 & 100.454 & -12.324 & -49.489 & -775.704 & 355 & 173.784 & 9.186 & 28.138 & -754.194 \\
\hline 205 & 103.139 & -11.815 & -46.977 & -775.195 & 360 & 175.755 & 10.060 & 30.583 & -753.320 \\
\hline 210 & 105.823 & -11.292 & -44.461 & -774.672 & 365 & 177.670 & 10.944 & 33.019 & -752.436 \\
\hline 215 & 108.498 & -10.756 & -41.940 & -774.136 & 370 & 179.536 & 11.837 & 35.449 & -751.543 \\
\hline 220 & 111.157 & -10.207 & -39.416 & -773.587 & 375 & 181.364 & 12.739 & 37.869 & -750.641 \\
\hline 225 & 113.795 & -9.645 & -36.889 & -773.025 & 380 & 183.178 & 13.650 & 40.283 & -749.730 \\
\hline 230 & 116.406 & -9.069 & -34.359 & -772.449 & 385 & 185.012 & 14.571 & 42.689 & -748.809 \\
\hline 235 & 118.985 & -8.481 & -31.828 & -771.861 & & & & & \\
\hline
\end{tabular}




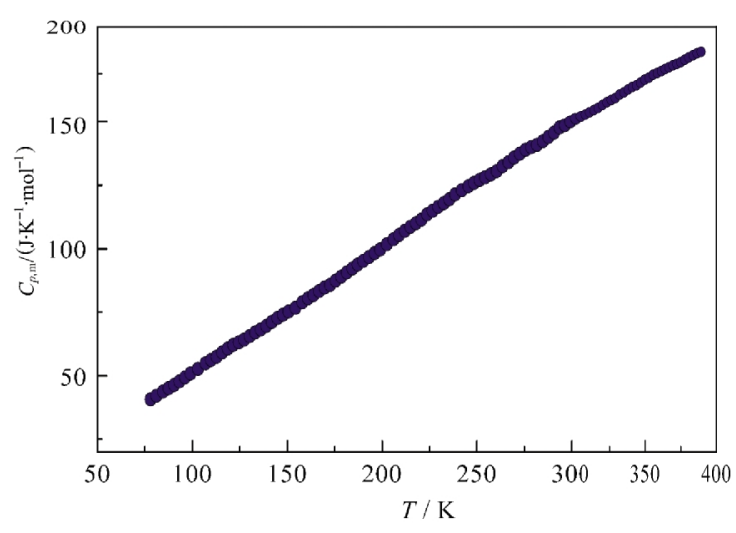

Fig.2 Experimental molar heat capacity $C_{p, \mathrm{~m}}$ of melamine versus temperature

$\mathrm{C}=\mathrm{N}$ are 293 and $615 \mathrm{~kJ} \cdot \mathrm{mol}^{-1}{ }^{[23]}$. It can be seen that the bond enthalpy of $\mathrm{C} \approx \mathrm{N}$ in melamine molecules is larger than that of single bond $\mathrm{C}-\mathrm{N}$ and less than that of double bond $\mathrm{C}=\mathrm{N}$.

The heat capacities of melamine were measured with the adiabatic calorimeter over the temperature range from 80 to $385 \mathrm{~K}$. The result is shown in Fig.2. The differences between 298.15 K and other temperatures for the formation enthalpy and entropy $\left(\Delta_{\mathrm{f}} H_{\mathrm{m}, 29.15 \mathrm{~K}}^{\ominus}-\Delta_{\mathrm{f}} H_{\mathrm{m}, T}^{\ominus}\right)$ and $\left(S_{\mathrm{m}, 298.15 \mathrm{~K}}^{\ominus}-S_{\mathrm{m}, T}^{\ominus}\right)$ were presented in Table 2. The temperature increment for each experimental point was about $3 \mathrm{~K}$ in the whole temperature range. No phase transition was observed in this temperature region. The data of the molar heat capacities of melamine between 80 and $385 \mathrm{~K}$ are very close to a straight line and can be represented by the following equation with a correlation coefficient of 0.9994 .

$C_{p, \mathrm{~m}}=3.61+0.483 T$

According to the value of $\Delta_{\mathrm{f}} H_{\mathrm{m}}^{\ominus}$, the standard molar enthalpy of formation for melamine in the temperature range from 80 to $385 \mathrm{~K}$ can be calculated, which is shown in Table 2 . To estimate the enthalpy of combustion of melamine with a wide range of temperature, the following recycle of thermo-chemistry was designed.

$$
\begin{gathered}
\mathrm{C}_{3} \mathrm{H}_{6} \mathrm{~N}_{6}(\mathrm{~s})+\frac{9}{2} \mathrm{O}_{2}(\mathrm{~g}) \Rightarrow 3 \mathrm{CO}_{2}(\mathrm{~g})+3 \mathrm{~N}_{2}(\mathrm{~g})+3 \mathrm{H}_{2} \mathrm{O}(\mathrm{l}) \\
\mathrm{C}_{3} \mathrm{H}_{6} \mathrm{~N}_{6}(\mathrm{~s})+\frac{9}{2} \mathrm{O}_{2}(\mathrm{~g}) \Rightarrow 3 \mathrm{CO}_{2}(\mathrm{~g})+3 \mathrm{H}_{2}(\mathrm{~g})+3 \mathrm{H}_{2} \mathrm{O}(\mathrm{l})
\end{gathered}
$$

According to data in Refs. [25,26], it can be known that $C_{p, \mathrm{~m}}\left(\mathrm{CO}_{2}\right)=$ $44.22+8.79 \times 10^{-3} T-8.62 \times 10^{5} T^{-2}, C_{p, m}\left(\mathrm{O}_{2}\right)=29.96+4.18 \times 10^{-3} T-1.67 \times$ $10^{5} T^{-2}, C_{p, \mathrm{~m}}\left(\mathrm{H}_{2} \mathrm{O}\right)=75.48, C_{p, \mathrm{~m}}\left(\mathrm{~N}_{2}\right)=28.58+3.76 \times 10^{-3} T-0.56 \times 10^{-6} T^{2}$.

$$
\Delta_{\mathrm{c}} H_{\mathrm{m}, T}^{\ominus}=\Delta_{\mathrm{c}} H_{\mathrm{m}, 298.15 \mathrm{~K}}^{\ominus}+\Delta H_{1}+\Delta H_{2}
$$

$$
\begin{aligned}
= & \Delta_{\mathrm{c}} H_{\mathrm{m}, 298.15 \mathrm{~K}}^{\ominus}+\int_{298.15}^{T} \Delta C_{p, \mathrm{~m}} \mathrm{~d} T \\
= & \Delta_{\mathrm{c}} H_{\mathrm{m}, 298.15 \mathrm{~K}^{+}}^{\ominus} \int_{298.15}^{T}(306.41-0.49 T- \\
& \left.1.68 \times 10^{-6} T^{2}-1.84 \times 10^{6} T^{-2}\right) \mathrm{d} T \\
\Delta_{\mathrm{c}} H_{\mathrm{m}}^{\ominus}= & -2455.17+\frac{306.41 T-0.245 T^{2}-0.56 T^{3}+1.84 \times 10^{6} T^{-1}}{1000}
\end{aligned}
$$

The TG-DTA measurements were carried out in $\mathrm{N}_{2}$ atmo-

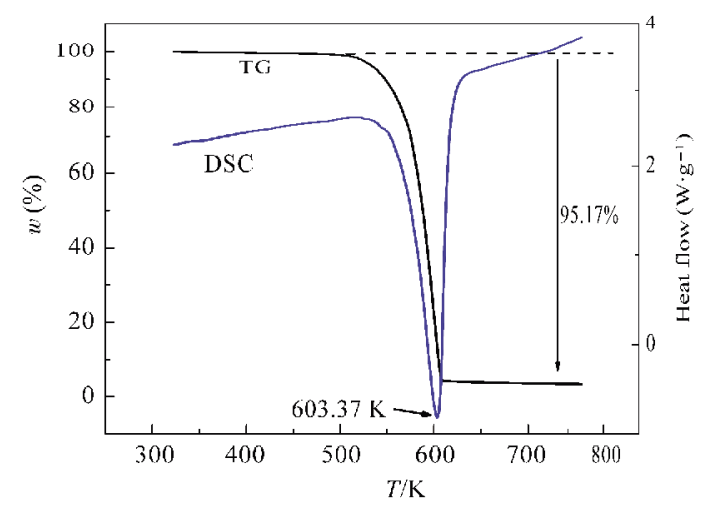

Fig.3 TG-DSC results of melamine from 323 to $773 \mathrm{~K}$

sphere. The TG-DSC results are presented in Fig.3. It can be seen from the mass-loss curve that most of the activities occur from 495.15 to $607.15 \mathrm{~K}$ in a single step. No residue was found in the crucible after the experiment was completed. An obvious peak was observed from the DSC curve. The peak was associated with heat decomposition of melamine. Between room temperature and $603.37 \mathrm{~K}$, no phase transition was observed.

\section{Conclusions}

The thermodynamic properties of melamine were studied by combination of several thermal chemistry technique, including the standard molar enthalpy of formation and the heat capacity over the temperature range from 80 to $385 \mathrm{~K}$. From the data, it can be seen that the value of the standard molar enthalpy of formation is high, which means that melamine is a very stable compound. There is a linear relationship between the molar heat capacities of melamine and temperature from 80 to $385 \mathrm{~K}$. Besides, according to the relation between the combustion enthalpy and the bond enthalpy, the bond enthalpy of $\mathrm{C} \approx \mathrm{N}$ in melamine was estimated. The value is smaller than that of $\mathrm{C}-\mathrm{N}$ and larger than that of $\mathrm{C}=\mathrm{N}$, which can be attributed to the tension of $\mathrm{C} \approx \mathrm{N}$ in cyclic melamine molecule. By providing the fundamental thermodynamics of melamine, this study is insightful to understanding the biological effect of melamine in vivo.

\section{References}

1 Yang, S. L.; Huang, S. L. Food and Drug, 2008, 10: 66

2 Roth, M.; Schwarzinger, C.; Mueller, U.; Schmidt, H. J. Anal. Appl. Pyrol., 2007, 79: 306

3 Chiu, S. H.; Wang, W. K. Polymer, 1998, 39: 1951

4 Xiao, J. F.; Hu, Y.; Yang, L.; Cai, Y. B.; Song, L.; Chen, Z. Y.; Fan, W. C. Polym. Degrad. Stabil., 2006, 91: 2093

5 Bertelli, G.; Camino, G.; Costa, L.; Locatelli, R. Polym. Degrad. Stabil., 1987, 18: 225

6 Sancho, J. V.; Ibáñez, M.; Grimalt, S.; Pozo, Ó. J.; Hernández, F. Anal. Chim. Acta, 2005, 530: 237

7 Roberts, R. J.; Evans, P. D. Compos. Pt. A-Appl. Sci. Manuf., 2005, 36: 95 
8 Gilfrich, H. P.; Rösinger, S.; Wilski, H. Radiat. Phys. Chem., 1992, 39: 273

9 Verma, P.; Rastogi, R. K.; Ramakumar, K. L. Anal. Chim. Acta, 2007, 596: 281

10 Doshi, J. B.; Ravetkar, S. D.; Ghole, V. S.; Rehani, K. Biologicals, 2003, 31: 187

11 Lengauer, W. Talanta, 1991, 38: 659

12 Dobson, R. L.; Motlagh, S.; Quijano, M.; Cambron, R. T.; Baker, T. R.; Pullen, A. M.; Regg, B. T.; Bigalow-Kern, A. S.; Vennard, T.; Fix, A.; Reimschussel, R.; Overmann, G.; Shan, Y.; Daston, G. P. Toxicol. Sci., 2008, 106: 251

13 Puschner, B.; Poppenga, R. H.; Lowenstine, L. J.; Filigenzi, M. S.; Pesavento, P. A. J. Vet. Digan. Invest., 2007, 19: 616

14 Heck, H. D.; Tyl, R. W. Regul. Toxicol. Pharmacol., 1985, 5: 294

15 Osborne, C. A.; Lulich, J. P.; Ulrich, L. K.; Koehler, L. A.; Albasan, H.; Sauer, L.; Schubert, G. Veterinary Clinics of North America: Small Animal Practice, 2007, 39: 1

16 Yang, X. W.; Chen, S. P.; Gao, S. L.; Li, H. Y.; Shi, Q. Z. Instrum. Sci. Technol., 2002, 30: 311

17 Certificate of analysis of standard reference material 39i-benzoic acid. Gaithersburg: National Institute of Standards and Technology, 1995
18 Experimental thermodynamics, Vol. 1. Calorimetry of non-reaction system. Westrum Jr., E. F.; Furukawa, G. T.; McCullough, J. P.; Scott, D. W. Eds. London: Butterworths, 1968: 133

19 Dong, J. X.; Li, Q.; Tan, Z. C.; Zhang, Z. H.; Liu, Y. J. Chem. Thermodyn., 2007, 39: 108

20 Tan, Z. C.; Sun, G. Y.; Song, Y. J.; Wang, L.; Han, J. R.; Liu, Y. S.; Wang, M.; Nie, D. Z. Thermochim. Acta, 2007, 247: 352

21 Tan, Z. C.; Sun, L. X.; Meng, S. H.; Li, L.; Xu, F.; Yu, P.; Liu, B. P.; Zhang, J. B. J. Chem. Thermodyn., 2002, 34: 1417

22 Brown, T.; Lemay, H. E.; Bursten, B. E. Chemistry-the central science. 7th ed. New Jersey: Prentice-Hall, 1997: 280

23 Fu, X. C.; Shen, W. X.; Yao, T. Y. Physical chemistry. Beijing: Higher Education Press, 1990: 83 [傅献彩, 沈文霞, 姚天扬. 物 理化学. 北京: 高等教育出版社, 1990: 83]

24 Cao, X. Z.; Zhang, W. H.; Do, X. G. Inorganic chemistry. Beijing: Higher Education Press, 1983: 163 [曹锡章, 张腕惠, 杜尧国. 无 机化学. 北京: 高等教育出版社, 1983: 163]

25 Barrow, G. Physical chemistry. 5th ed. Columbus: McGraw-Hill Book Company, 1988: 126

26 Liu, P.; Xu, J. J.; Ma, F. Q.; Li, X.; Zhang, C. C. J. Therm. Anal. Calorim., 2008, 93: 485 